\title{
GNSS測量と空中写真測量による 2016年熊本地震の地表面の変状の分析
}

\author{
久保寺 貴彦 1 - 鈴木 崇伸 2 - 政春 尋志 3 ・松尾 栄治 4 \\ 1正会員 東洋大学助教 理工学部都市環境デザイン学科（テ350-8585 埼玉県川越市鯨井2100） \\ E-mail: kubodera@toyo.jp \\ 2正会員 東洋大学教授 理工学部都市環境デザイン学科（テ350-8585 埼玉県川越市鯨井2100） \\ E-mail: tsuzuki@toyo.jp \\ 3正会員＼cjkstart東洋大学教授＼cjkstart理工学部都市環境デザイン学科（テ350-8585 埼玉県川越市鯨井2100） \\ E-mail: masaharu@toyo.jp \\ 4正会員 九州産業大学准教授 工学部都市基盤デザイン工学科（†813-8503 福岡市東区松香台2-3-1） \\ E-mail: ematsuo@ip.kyusan-u.ac.jp
}

\begin{abstract}
2016年熊本地震による地表面の変状を明らかにするため, 現地にてGNSS測量を行うとともに空中写真 測量により地表面の3Dモデルを作成した。 また，検証点において，作成したモデルの位置精度を検証した。 作成した震災後の地表モデルをGISにより震災前の地表モデルに重ね合わせて，地表面の変状を分析する こととした．阿蘇市的石・永草地域において，震災前後DEMの差分を解析した。その結果，鉛直変状を面 的かつ定量的に明らかにすることができた. さらに, 益城町安永地域において, 震災前後のマスとマンホ ールの中心位置の座標值を計測した. その結果, 水平変状を面的かつ定量的に明らかにすることができた.
\end{abstract}

Key Words : aerial-photogrammetry, GNSS, DEM, GIS

\section{1. はじめに}

2016年熊本地震は震源が浅かったために大きな摇れが 起きたことに加え，震源域に断層変位が生じて甚大な被 害となった。今回の震源域においては断層線に沿って地 表面の変状が確認されている1)-3). 上・下水道管などの ライフライン構造物は, 線状に構築されており, 地表面 の変状を受けやすく圧縮，引つ張りや曲げによって破壊 に至る. 断層を考慮したライフライン構造物の設計法は 確立しておらず，地表面とライフライン構造物の変状を 明らかするために，地表面の変状の分析が必要である.

最近はリモートセンシング技術の進展が著しく，国土 の詳細なデータベースが整備され，観測体制が整ってい る.今回の熊本地震でも多くの最新測量技術により，被 害把握が試みられている1)-9). 中でも，2014年5月に打ち 上げたALOS-2に関する報告が多い11,5),9)。ALOS-2は，熊 本県全域をカバーしており，搭載したセンサPALSAR-2 は，天候に左右されず，昼夜を問わずに地表面を観測可 能であり，地震による地款変動を衛星への視線方向につ いては相対的に0.02 $\mathrm{m}$ の精度で計測できる利点がある一
方，光学センサを搭載していないので，カラー写真は撮 影できない欠点がある. 災害状況をより直感的に判読す るには，空中写真が必須であり，空中写真を用いた変状

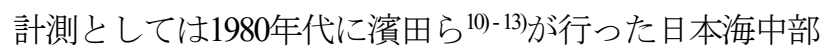
地震の液状化による地盤変状の分析が有名である.

本研究の目的は, 熊本地震の震源域における複数の空 中写真測量，および現地におけるGNSS測量を通して地 表面の三次元(以下，3Dという)モデルを作成し，地表面 の変状を明らかにすることで，地表面で確認できるライ フライン構造物の被害との対比分析に役立てることであ る. なお, ライフライン構造物は, マスとマンホールに 着目した. 著者らは, 被害状況の正確な位置を明らかに するため，作成した3DモデルをGISへ展開して，震災前 の地表面に重ね合わせるべきと考え，さらに，震災前後 の地表面の変状を面的かつ定量的に明らかにするために， 着目地域における震災前後の較差を算出した。 なお，空 中写真測量の際のGCP (Ground Control Point)を得るために, 現地にてネットワーク型RTK法VRS (Virtual Reference Station)方式のGNSS測量を行った. 


\section{2. 研究の概要}

震災後，益城町の住宅被害や阿蘇大橋近傍の大規模土 砂災害が最も早く注目4),8)されたが，これらに比べて阿 蘇市的石・永草地域の地表面の鉛直変状の被害報告は少 ない.このことから，阿蘇市的石・永草地域において， 地表面の鉛直変状を明らかにするため, 作成した震災後 DEMを震災前DEMと比較して差分を算出することとし た．さらに，住宅被害が著しい益城町において，地表面 の変状とライフライン構造物の被害と対比分析に役立て るよう，益城町安永地域の水平変状を明らかにすること とした。 このため, 作成した震災後3Dモデルからマン ホールとマスの中心位置を算出して，震災前の空中写真 のマンホールとマスの中心位置と比較して較差ベクトル を算出することとした．最近ではドローンによる測量が 行われているが，震災前の地表モデルは，航空機から測 量された成果であるので，震災後の地表モデルを震災前 の地表モデルと比較する場合には，航空機による空中写 真測量が適していると考えられる.

\section{(1) 対象地域と空中写真}

空中写真の標定図を図-1に示寸，青丸が示寸空中写真 は，布田川断層帯周辺の地表の亀裂の分布に沿って撮影 されている．撮影したデジタルカメラは，キャリブレー ションがされて内部定位が明確であり，RTK法GNSS測 量とIMUによって，撮影時のカメラの3D座標值と姿勢 が正確に得られている．図-1(a)は，阿蘇市的石・永草地 域を含む阿蘇3地区であり，空中写真の撮影日は，2016 年7月 5 日である。このうち，1コースの空中写真につい て, 空中写真測量を行った. 図-1(b)は, 益城町安永地域 を含む熊本断層地区Bであり，空中写真の撮影日は， 2016年4月29日である.このうち，2コースの空中写真に ついて, 空中写真測量を行った.

\section{(2) 実施したGNSS測量}

2016年7月23日と24日の両日，著者らは，GCPの3D座 標值を求めるため, ネットワーク型RTK法VRS方式の GNSS測量を実施した(写真-1)。使用したGNSS測量機は, Trimble R10である．使用した衛星は，GPS，GLONASS々 QZSSの3種であり，使用した周波数帯はL1とL2の2周波 である. 使用したジオイド・モデルは，日本のジオイド 2011 Ver 1.0である. GCPは，撮影コースの四隅，車で入 れる地点，空中写真に明瞭に映っている舗装のライン標 示に着目して選点した。測量計算の結果，GNSS測量に よる最確值の標準偏差は，0.01 m程度であった。

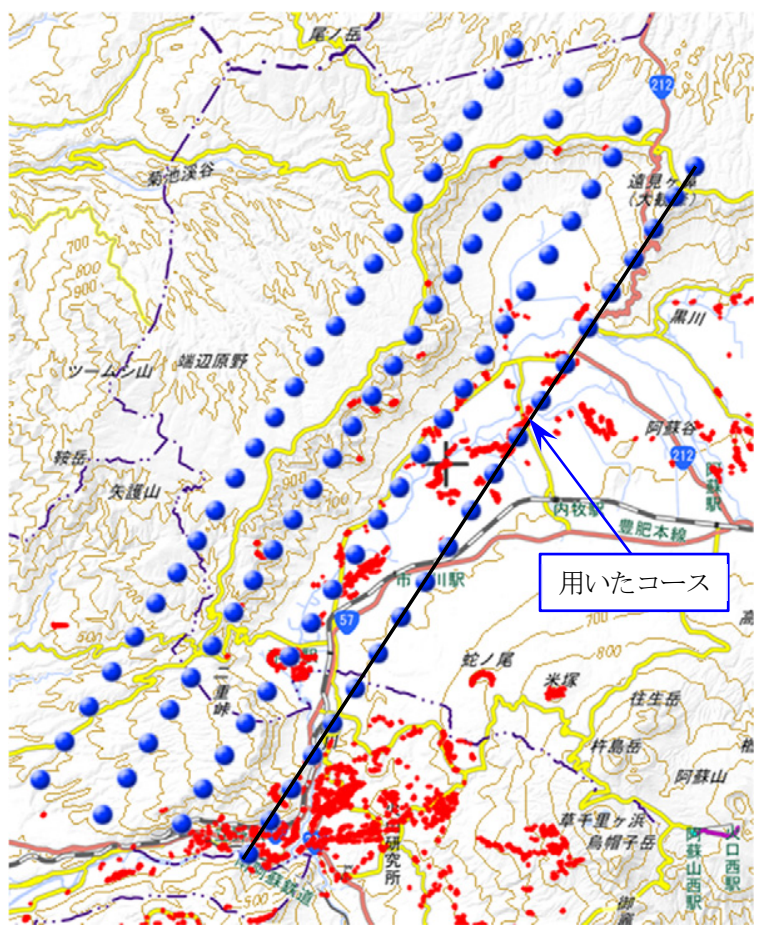

(a) 阿蘇市的石・永草地域を含む阿蘇 3 地区

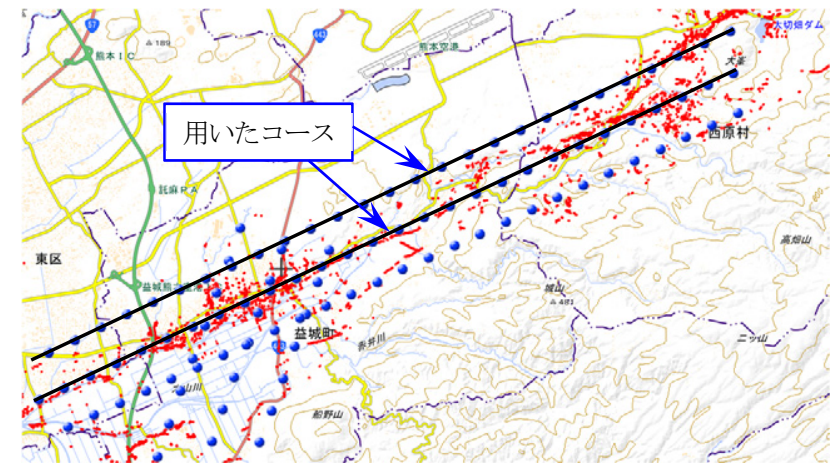

(b) 益城町安永地域を含む熊本断層地区 $\mathrm{B}$

図-1＼cjkstart空中写真の標定図(赤丸は，国土地理院による 布田川断層帯周辺の地表の亀裂の分布図)

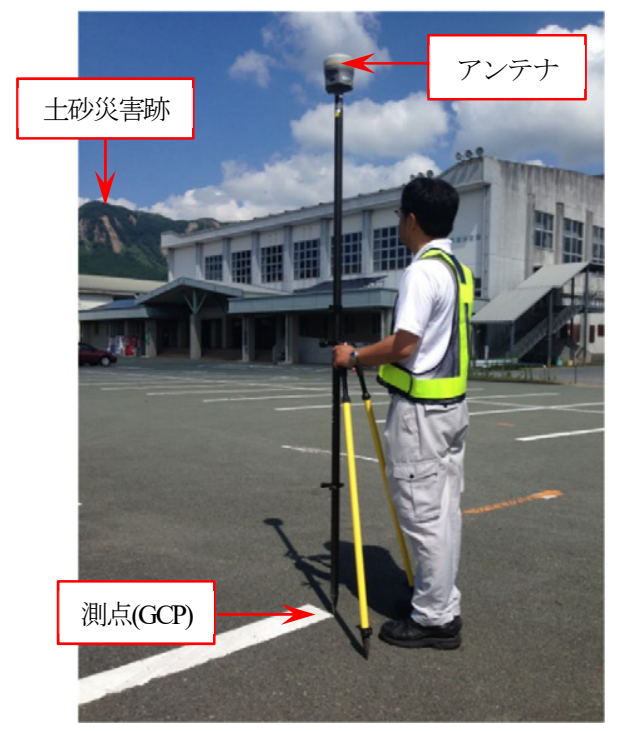

写真-1＼cjkstart実施したネットワーク型 RTK 法 VRS 方式の GNSS 測量 


\section{3. 実施した空中写真測量}

使用した写真測量ソフトウェアは，PhotoScan Professionalである. PhotoScan Professionalは複数の空中写真と複 数のGCPを用いて自動的に空中三角測量可能である.ま た，イメージマッチングによりDSMの3D点群を自動的 に作成でき，グラウンドに分類したポイントクラウド のみを使用することでDEMを作成可能である．さらに， オルソフォトモザイクを自動的に作成可能である.

作成した3Dモデルを図-2に示す．図-2(a)は，阿蘇市的 石・永草地域を含む阿蘇3地区であり，図-2(b)は，益城

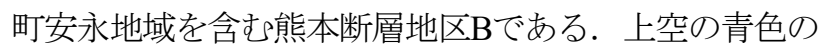
長方形が空中写真の3D位置と姿勢を示していて，地表 面の丸がGNSS測量を実施したGCPの3D位置を示してい ている. 空中写真測量の結果, 地表面の3D点群モデル が作成できた.

空中三角測量を行った結果，設定したGCPの最確值の 残差の標準偏差を表-1に示寸. 表-1 (a)は，阿蘇市的石・ 永草地域を含む阿蘇3地区における $\mathrm{GCP}$ 点の最確值の残 差の標準偏差であり, 平面直角座標系 $X$ と $Y$, 標高 $H$ の標 準偏差は，すべて $0.15 \mathrm{~m}$ 以内であった．表-1 (b)は，益城 町安永地域を含む熊本断層地区BにおけるGCP5点の最確 值の残差の標準偏差であり, 平面直角座標系 $X$ と $Y$, 標 高Hの標準偏差は，すべて0.06 m以内であった．なお， 熊本断層地区Bでは, GCPの最確值の残差が大きい地点 を外して空中三角測量を行ったため, 阿蘇3地区より高 い精度であった.

イメージマッチングにより震災後DSMの3D点群を自 動的に作成した．阿蘇市的石・永草地域において，震災

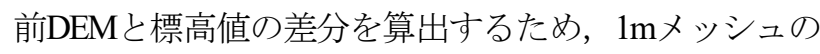
震災後DEMのラスター形式を作成した.

阿蘇市的石・永草地域において被害状況を判読できる ようにするため, 益城町安永地域において水平変状を明 らかにするため，それぞれ3D点群と空中写真からオル ソフォトモザイクをラスター形式で作成した.

\section{4. 阿蘇市的石・永草地域における鉛直変状}

\section{(1) オルソフォトモザイクによる断層亀裂の位置特定}

作成したオルソフォトモザイクをGISに展開した(図-3). 座標系は，日本測地系2011の平面直角座標系第2系を用 いた．使用したGISソフトウェアは，ArcGIS 10.4.1である. 位置確認のため，背景地図は地理院地図を用いた。この 結果，作成したオルソフォトモザイクは，然るべき位置 に展開できていることがわかる．作成したオルソフォト モザイクから確実に陷没が見られる箇所を特定して，才 ルソフォトモザイクを透過率50\%にして既存地図に重祆

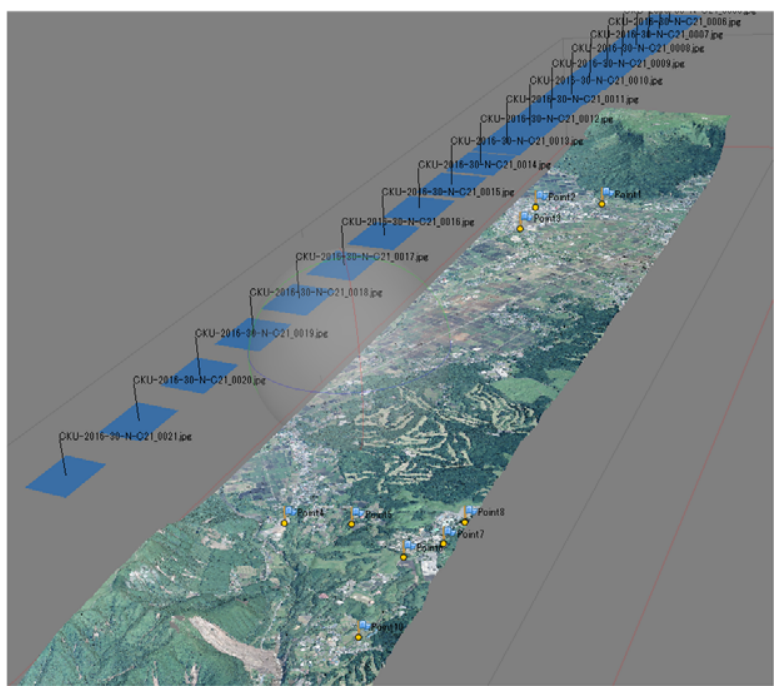

(a) 阿蘇市的石・永草地域を含む阿蘇 3 地区

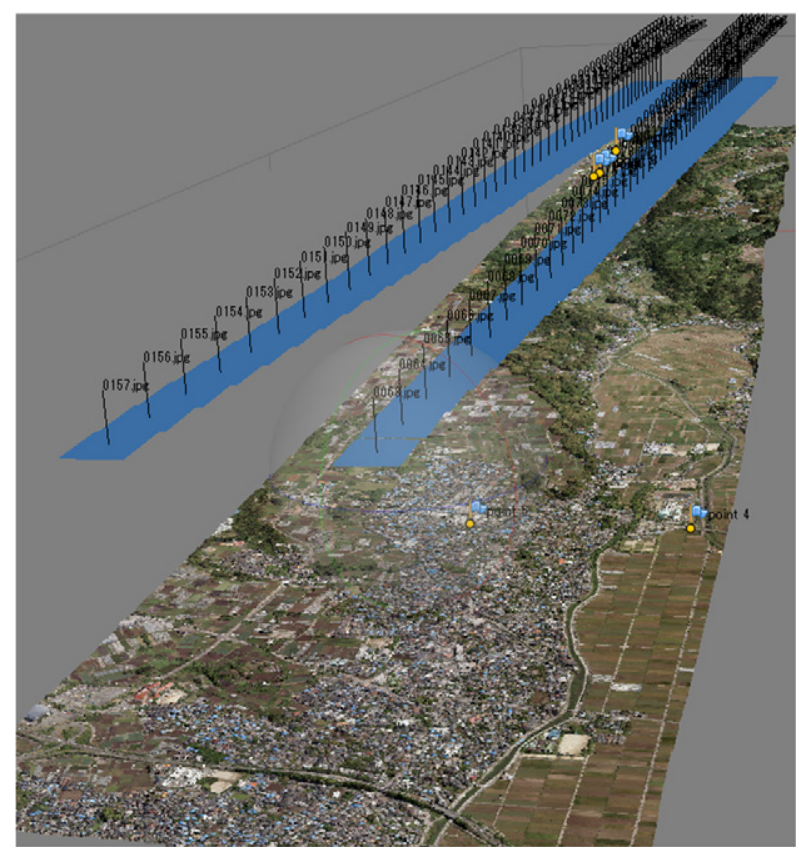

(b) 益城町安永地域を含む熊本断層地区 $\mathrm{B}$

図-2＼cjkstart空中写真測量により作成した 3D モデル

表-1 空中三角測量 GCP の最確值の残差の標準偏差

(a) 阿蘇 3 地区における GCP9 点

\begin{tabular}{c|c|c|c}
\hline & $X[\mathrm{~m}]$ & $Y[\mathrm{~m}]$ & $H[\mathrm{~m}]$ \\
\hline 標準偏差 & 0.088 & 0.149 & 0.149 \\
\hline
\end{tabular}

(b) 熊本断層地区 $\mathrm{B}$ における GCP5 点

\begin{tabular}{c|c|c|c}
\hline & $X[\mathrm{~m}]$ & $Y[\mathrm{~m}]$ & $H[\mathrm{~m}]$ \\
\hline 標準偏差 & 0.027 & 0.042 & 0.058 \\
\hline
\end{tabular}

たことで被害状況の正確な位置を明らかにすることが可 能となった(図-4). 水田地帯に発生した断層の亀裂を確 認できる.

第二著者が震災直後に, 着目した水田地帯周辺を撮影 した(写真-2). 水田地帯に幾つかの断層亀裂が生じてい 


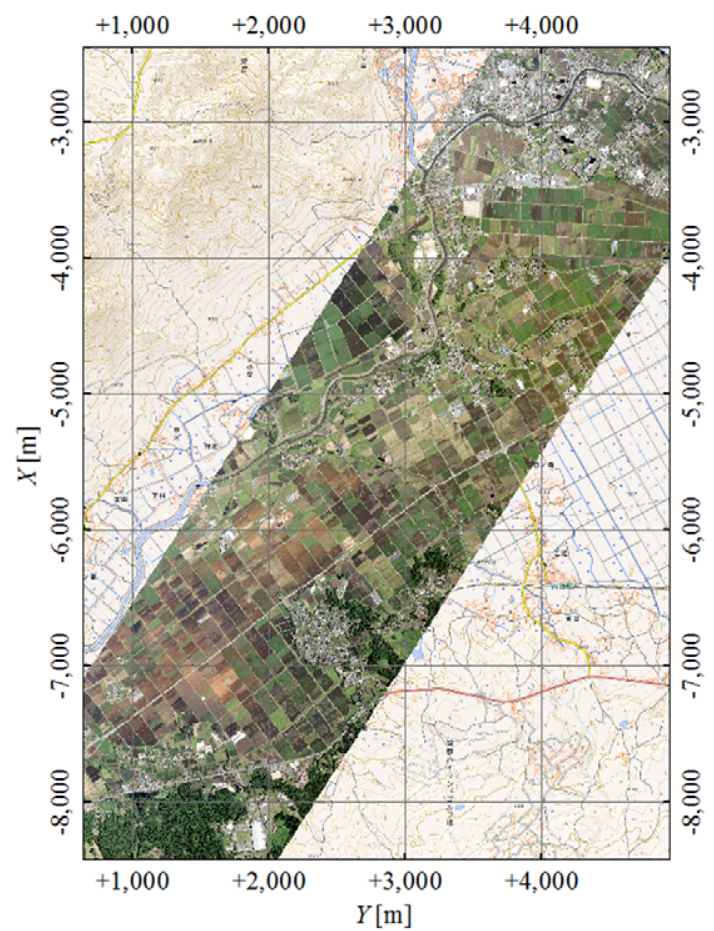

図-3＼cjkstart作成したオルソフォトモザイクを GISに展開

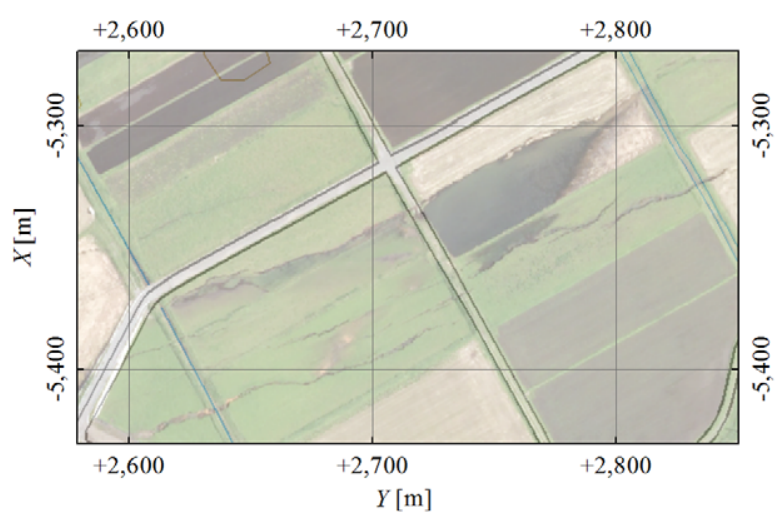

図-4 水田地帯に発生した断層の亀裂を特定

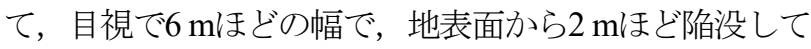
いる.

\section{(2) 震災前後DEMの差分}

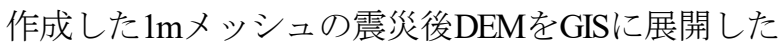
(図-5). 標高 $490 \mathrm{~m}$ ほどの比較的平坦な地帯であるが，北 西に向かって徐々に低くなっていく地带であることが確 認できる.

震災前DEMは，基盤地図情報の2015年の成果 $(5 \mathrm{~m}$ メッ シュ, 標高值 $0.01 \mathrm{~m}$ 単位, 航空レーザ測量成果)を用いた. 震災前後DEMの差分の解析のため, 震災前DEM と震災 後DEMのメッシュサイズをそれぞれ1mに揄えた，測量 分野において，重多に距離を用いることが多いため，内 挿法は，IDW (Inverse Distance Weighted)法を用いた.

震災前後DEMの差分を解析した結果を図-6に示す，標 高值を示すピクセル值について，震災前DEMを基準と したので, 差分結果は(震災後DEM一震災前DEM)とした。

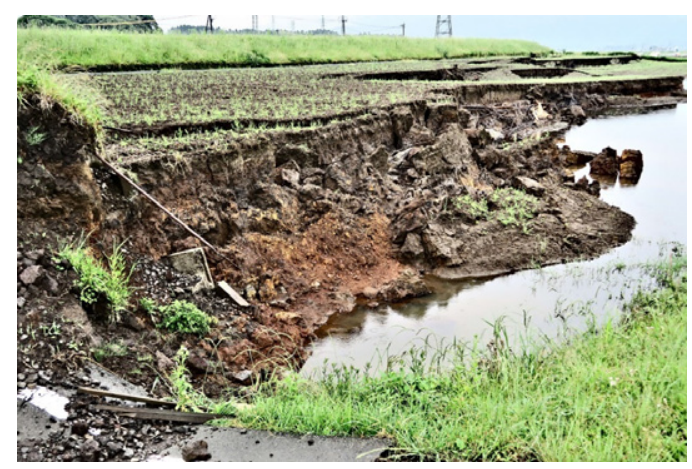

写真-2 着目した水田地帯周辺の震災直後の様子

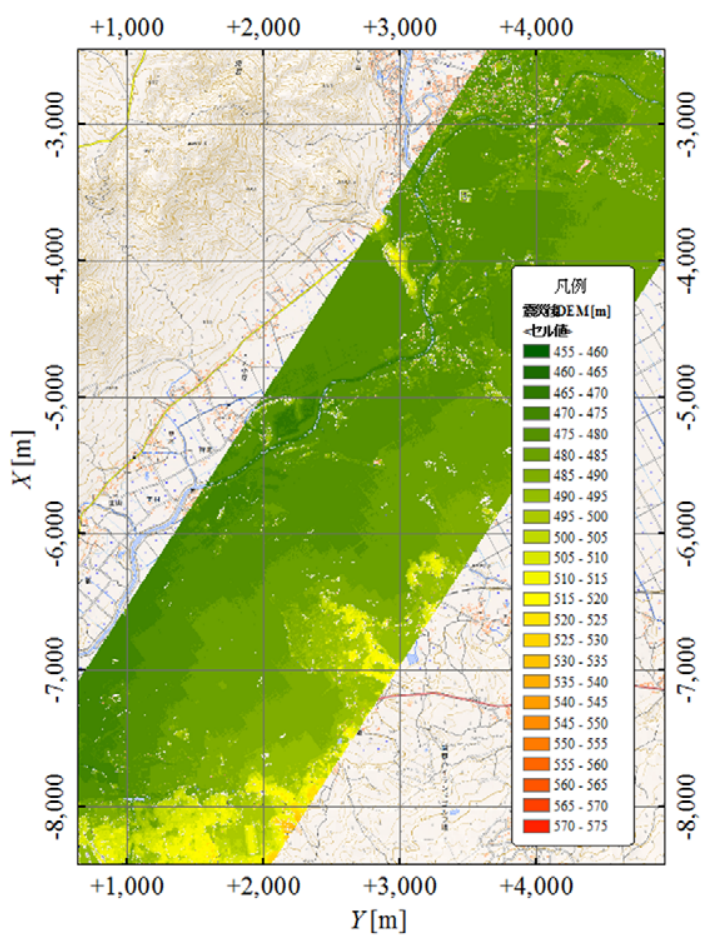

図-5＼cjkstart作成した震災後 DEMを GIS に展開

$3 \mathrm{~m}$ 以上の明らかな高低差がある箇所は，森林と建物相 当と考えられるので，黒色とした。メッシュサイズは1 mである. 震災前後DEMの差分により，鉛直変状を面的 かつ定量的に明らかにすることができた. 解析結果から，

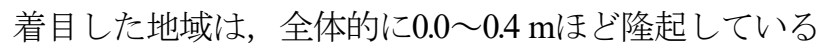
と考えられる. 水田は, 農道に比べて隆起を示している が，特徴のない箇所ではイメージマッチングが正確性に 欠ける可能性が考えられる. なお，近傍の水準点 2 点に おいて，国土地理院が水準測量を実施した結果，+ 0.16 $\mathrm{m}$ と $+0.09 \mathrm{~m}$ の変動量がわかっている ${ }^{14}$.

\section{(3) 震災前DEMと震災後GNSS測量との標高値の較差}

震災前後DEMの差分の数值を検証するため, 現地に てGNSS測量を行った地点のうち空中写真の標定用GCP に用いなかった別の地点(以下，検証点という)において 震災後DEM，震災前DEMの標高值および差分を比較し た(表-2)。この結果から，これら検証点では，震災後 
DEMと震災後GNSSの標高值は近似していて, 較差は +0.031 m〜+0.196 mであった．また，震災後GNSSの標高 值を真値と仮定したときの震災後DEMの標高值の標準 偏差は， $0.118 \mathrm{~m}$ であった．才なわち，これら検証点にお いて, 震災後DEMは標準偏差0.118 mの精度で確からし いといえる. また, 差分から一様に隆起していることが 示された.

\section{(4) 震災前後DEMの横断図での比較}

図-6の中心の長方形の箇所おいて, 震災前後の差分が 見られていなくても，図-4のオルソフォトモザイクから 陥没が確認できる箇所が存在した。 これは，全体的に隆 起して, 局所的に下がった可能性が考えられる.このた め, 震災前後DEMを横断図で比較することとした. 図-7 に, 着目した横断線と震災前後DEMの差分を示す。こ の地域は，図-4で示した地域と同一である。実際には, 陷没しているものの，震災前後DEMでは差分があまり ない結果である. 周囲が隆起して, 相対的に陷没が生じ たものと考えられる. A点から $3 \mathrm{~m}$ 離れた地点を $B$ 点, 20 m離れた地点をC 点, 30 m離れた地点をD点, 60 m離れた 地点をE点, 70 m離れた地点を $F$ 点とした. 図-8に, 着目 した横断図を示す，A点からB点までは，舗装された農 道であり, 地震によって約 0.9 mほど隆起していること がわかる.A点からC点まではこの隆起が続いている. しかし，C点からE点までは震災前より急激に沈下して いることがわかる．沈下が最も深い $D$ 点では，地表面か ら約 $2 \mathrm{~m}$ 高低差があることがわかる．F点からA'点まで は, 再び隆起の状態に戻っていることがわかる. 震災後 DEMの波形は, 農道に比べて水田地帯が乱れている. これは，植生のような明確でない箇所ではイメージマッ チングが正確性に欠けると考えられる. 全体としては, 断層の亀裂による鉛直変状を面的かつ定量的に明らかに することができた.

\section{5. 益城町安永地域における水平変状}

\section{(1) 震災前マンホールとマスの中心位置の座標値計測}

益城町安永地域における震災前マンホールとマスの中 心位置の座標値を求める場合, 台帳図の位置精度は低い ことがわかっている15ことから，それ以上の精度が期待 できるよう震災前の空中写真1枚について, 震災前の街 区多角点に着目して幾何補正を行った，さらに，幾何補 正の精度を高めるため, 着目地域を高低差や写真の歪み の影響が少なくなるよう実際にライフライン構造物の被 害が確認されている地域周辺に狭めて, 幾何補正の参照 点を設定することとした．参照点には，震災前の街区多 角点の座標值 ${ }^{19}$ 入力した.

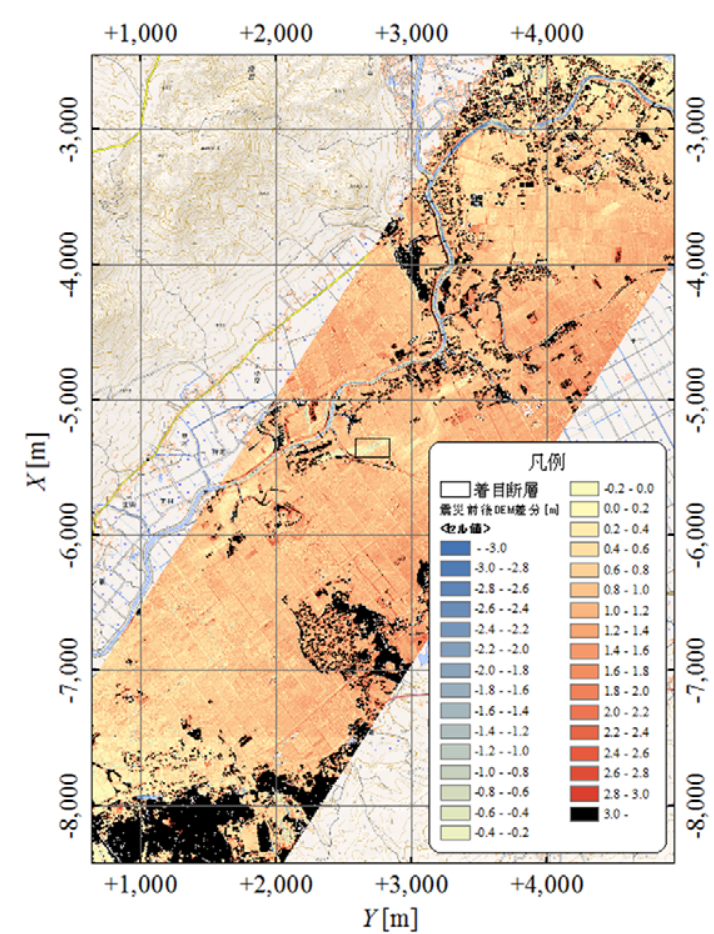

図-6 震災前後 DEM の差分

表-2 検証点における標高值と差分の比較

\begin{tabular}{|c|c|c|c|c|c|c|}
\hline \multirow[b]{2}{*}{ 点名 } & \multicolumn{3}{|c|}{ 標高値 [m] } & \multicolumn{2}{|c|}{ 差分 [m] } & \multirow[b]{2}{*}{ 較差 $[\mathrm{m}]$} \\
\hline & $\begin{array}{c}\text { 震災後 } \\
\text { GNSS }\end{array}$ & $\begin{array}{c}\text { 震災後 } \\
\text { DEM }\end{array}$ & $\begin{array}{c}\text { 震㷋前 } \\
\text { DEM }\end{array}$ & \begin{tabular}{|c|} 
震災後 \\
GNSS と \\
震災前 \\
DEM \\
\end{tabular} & $\begin{array}{c}\text { 震災後 } \\
\text { DEM と } \\
\text { 震災前 } \\
\text { DEM }\end{array}$ & \\
\hline 1 & 482.577 & 482.608 & 482.437 & +0.140 & +0.171 & +0.031 \\
\hline 2 & 479.888 & 479.938 & 479.605 & +0.283 & +0.333 & +0.050 \\
\hline 3 & 478.084 & 478.280 & 477.911 & +0.173 & +0.369 & +0.196 \\
\hline
\end{tabular}

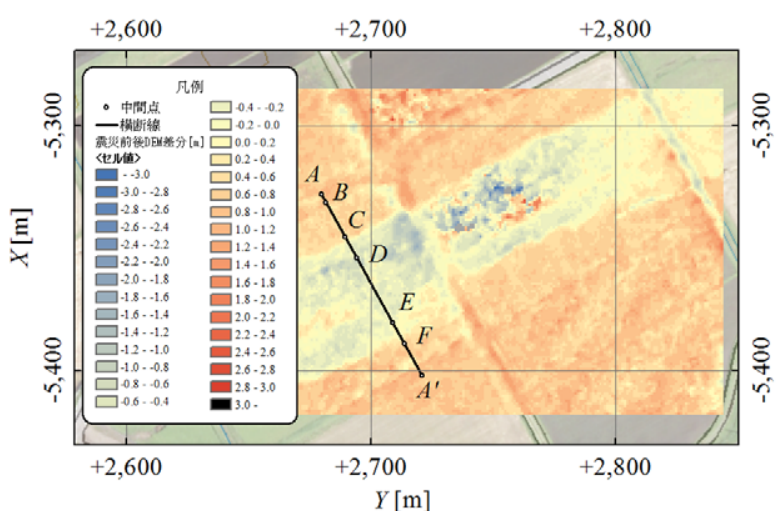

図-7 着目した横断線と震災前後 DEM の差分

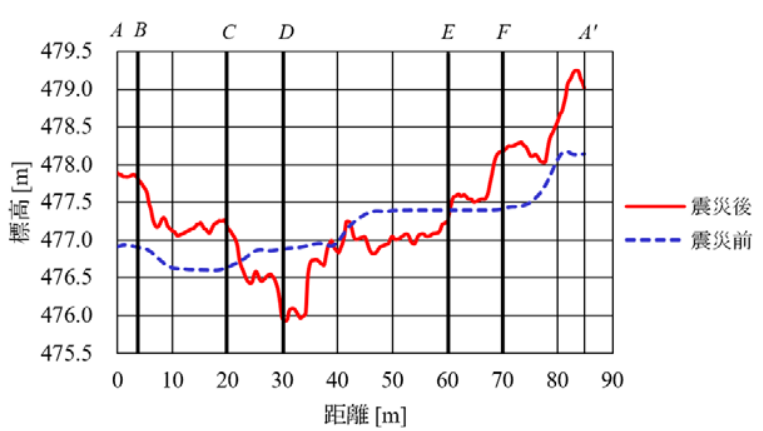

図-8 着目した横断図 
図-9に，幾何補正した震災前の空中写真を示す．使用 した空中写真は2008年10月撮影の撮影縮尺1/10000であり， 使用した街区多角点の座標值は2006年1月7日と9日の成 果である. 着目地域を実際に路面の変状が大きい地区に 注目して，この地域周辺について，参照点を4点設定し て，アフィン変換を行った. その結果，RMSEは， 0.165 mであった。直接観測された街区多角点の座標值を幾何 補正の参照点としたことで，比較的高い精度で幾何補正 が行われたと考えられる。この幾何補正した震災前の空 中写真から震災前マンホールとマスの中心位置座標を計 測することが可能になった.

\section{（2）作成した震災後オルソフォトモザイクの水平位置精 度の検証}

作成した震災後オルソフォトモザイクの水平位置精度 を検証するため, 現地にてGNSS測量を行った地点のう ち，検証点においてGNSS測量およびオルソフォトモザ イクの座標值を比較した(表-3). これらから, GNSSの座 標值を真值と仮定したときのオルソフォトモザイクの $X$ 座標值の標準偏差は0.042 mであり，Y座標値の標準偏差 は0.109 mであった。辺長を算出すると，作成した震災後 オルソフォトモザイクの水平位置は標準偏差 $0.117 \mathrm{~m}$ の精
度で確からしいことが確認された。この標準偏差 $0.117 \mathrm{~m}$ は，ネットワーク型RTK法VRS方式GNSS測量による標 準偏差 $0.01 \mathrm{~m}$ 程度より大きいものの, 台帳図による標準

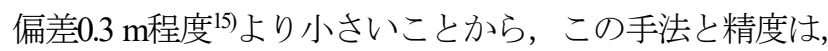
ライフライン構造物の被害との対比を目的として，災害 によってGNSS測量をライフライン構造物に対して行え ない場合，有効であると考えられる。

\section{(3) 震災前後マンホールとマスの中心位置の較差ベクト ル}

判読可能なマンホールとマスに注目して変位計算を行 った. 震災後マンホールとマスの中心位置座標は，作成 したオルソフォトモザイクから計測した。計測した震災 前後マンホールとマスの中心位置座標, 較差ベクトルの 方向角と長さを表-4に示す. 着目したマンホール2点と マス6点の計8点について，較差ベクトルの方向角は，平

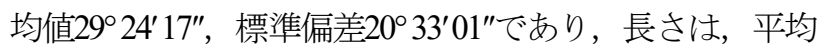
值 $0.609 \mathrm{~m}$ ，標準偏差 $0.173 \mathrm{~m}$ であった. 方向角の標準偏差 が大きいことは，マンホールとマスの震災前後の位置が 近いことに起因すると考えられる．精度向上のためには， 震災前のマンホールとマスの位置計測の精度を高める必 要があるので, 高い地上分解能の空中写真の入手, 幾何

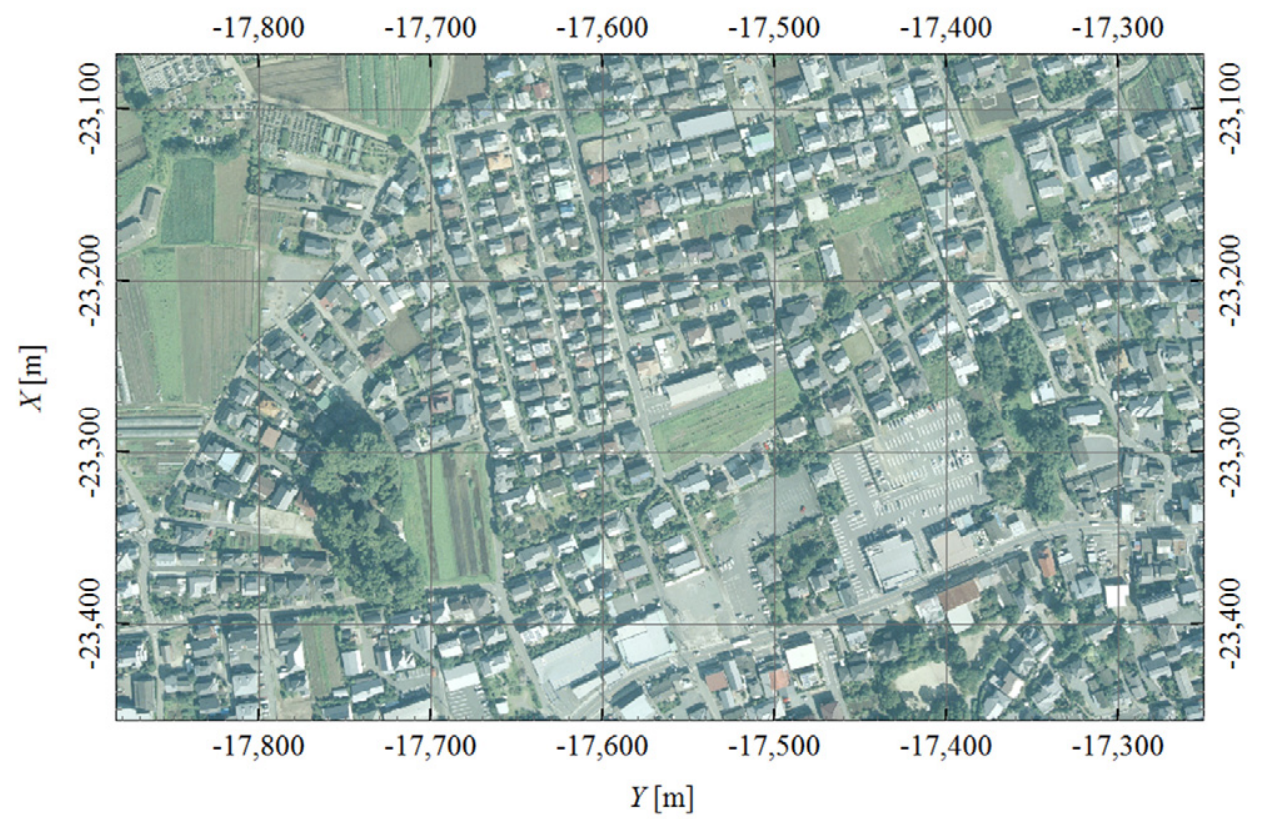

図-9 幾何補正した震災前の空中写真(2008年 10 月撮影)

表-3 検証点における GNSS 測量とオルソフォトモザイクの座標值の比較

\begin{tabular}{c|cc|cc|cc}
\hline \multirow{2}{*}{ 点名 } & \multicolumn{2}{|c|}{ GNSS 測量 } & \multicolumn{2}{|c|}{ オルソフォトモザイク } & \multicolumn{2}{c}{ 較差 } \\
\hline 1 & $X[\mathrm{~m}]$ & $Y[\mathrm{~m}]$ & $X[\mathrm{~m}]$ & $Y[\mathrm{~m}]$ & $X[\mathrm{~m}]$ & $Y[\mathrm{~m}]$ \\
\hline 2 & -23019.735 & -17238.494 & -23019.683 & -17238.361 & +0.052 & +0.133 \\
3 & -23881.407 & -16762.981 & -23881.394 & -16763.075 & +0.013 & -0.094 \\
\hline
\end{tabular}


土木学会論文集A1 構造 地震工学), Vol. 73, No. 4 她震工学論文集第36巻), I_592-1_600, 2017.

表-4＼cjkstart計測した震災前後マンホールとマスの中心位置座標，較差ベクトルの方向角と長さ

\begin{tabular}{|c|c|c|c|c|c|c|}
\hline \multirow[b]{2}{*}{ 点名 } & \multicolumn{2}{|c|}{ 震災前の水平位置 } & \multicolumn{2}{|c|}{ 震災後の水平位置 } & \multicolumn{2}{|c|}{ 較差ベクトル } \\
\hline & $X[\mathrm{~m}]$ & $Y[\mathrm{~m}]$ & $X[\mathrm{~m}]$ & $Y[\mathrm{~m}]$ & 方向角 [ddmmss] & 長さ [m] \\
\hline マス1 & -23219.240 & -17594.069 & -23218.868 & -17593.568 & $53^{\circ} 24^{\prime} 20^{\prime \prime}$ & 0.624 \\
\hline マス2 & -23229.633 & -17591.508 & -23229.358 & -17591.150 & $52^{\circ} 28^{\prime} 12^{\prime \prime}$ & 0.451 \\
\hline マス3 & -23241.529 & -17588.421 & -23241.199 & -17588.234 & $29^{\circ} 32^{\prime} 20^{\prime \prime}$ & 0.379 \\
\hline マス4 & -23252.373 & -17585.664 & -23251.826 & -17585.520 & $14^{\circ} 44^{\prime} 56^{\prime \prime}$ & 0.566 \\
\hline マス5 & -23263.232 & -17582.902 & -23262.696 & -17582.625 & $27^{\circ} 19^{\prime} 46^{\prime \prime}$ & 0.603 \\
\hline マス6 & -23274.037 & -17580.133 & -23273.265 & -17580.073 & $04^{\circ} 26^{\prime} 39^{\prime \prime}$ & 0.774 \\
\hline マンホール1 & -23236.383 & -17588.784 & -23236.075 & -17588.371 & $53^{\circ} 17^{\prime} 09^{\prime \prime}$ & 0.515 \\
\hline マンホール2 & -23281.732 & -17577.093 & -23280.770 & -17577.092 & $00^{\circ} 03^{\prime} 34^{\prime \prime}$ & 0.962 \\
\hline & & & & 平均值 & $29^{\circ} 24^{\prime} 17^{\prime \prime}$ & 0.609 \\
\hline & & & & 標準偏差 & $20^{\circ} 33^{\prime} 01^{\prime \prime}$ & 0.173 \\
\hline
\end{tabular}

補正用の多数の参照点確保のために現地にてTS(Total Station)とプリズムによって街区多角点からの多数点の偏心 観測などが考えられる.

図-10に，震災前後マンホールとマスの中心位置の較 差ベクトルを示す，背景地図は，オルソフォトモザイク (2016年4月)である. 強調のため, 較差べクトルの長さを 20倍とした．較差ベクトルの方向角と長さは似た傾向で はあるが，個々に異なっていることが確認できる．なお， 近傍の三角点1点において, 国土地理院が再測を実施し た結果, 北東に $0.80 \mathrm{~m}$ 程度の変動量がわかっている ${ }^{14)}$ とから, 本研究の提案手法による成果は, 三角点の変動 量との整合性が認められる．また，本研究の提案手法に よる成果は，三角点と異なって面的に水平変状を明らか にでき, 地款変動による複雑な地表面の変状を捉えられ る可能性を示した. さらに, 地表面のライフライン構造 物の変状を個別に着目できるため, 地表面の変状とライ フライン構造物の被害との対比分析に役立てる可能性を 示唆した.

\section{6. おわりに}

地表面の変状を明らかにするため, 現地でGNSS測量 を行って空中写真測量により地表面の3Dモデルを作成 した．作成した震災後の地表モデルをGISにより震災前 の地表モデルを重ね合わせて, 地表面の変状を分析した. その結果, 次の事柄が得られた.

1) 作成したオルソフォトモザイクを半透明にして既存 地図に重ねたことで被害状況の正確な位置を明らか にすることが可能となった.

2) 阿蘇市的石・永草地域において, 震災前後DEMの 差分を解析した，その結果，鉛直変状を面的かつ定 量的に明らかにすることができ，着目した地域は，

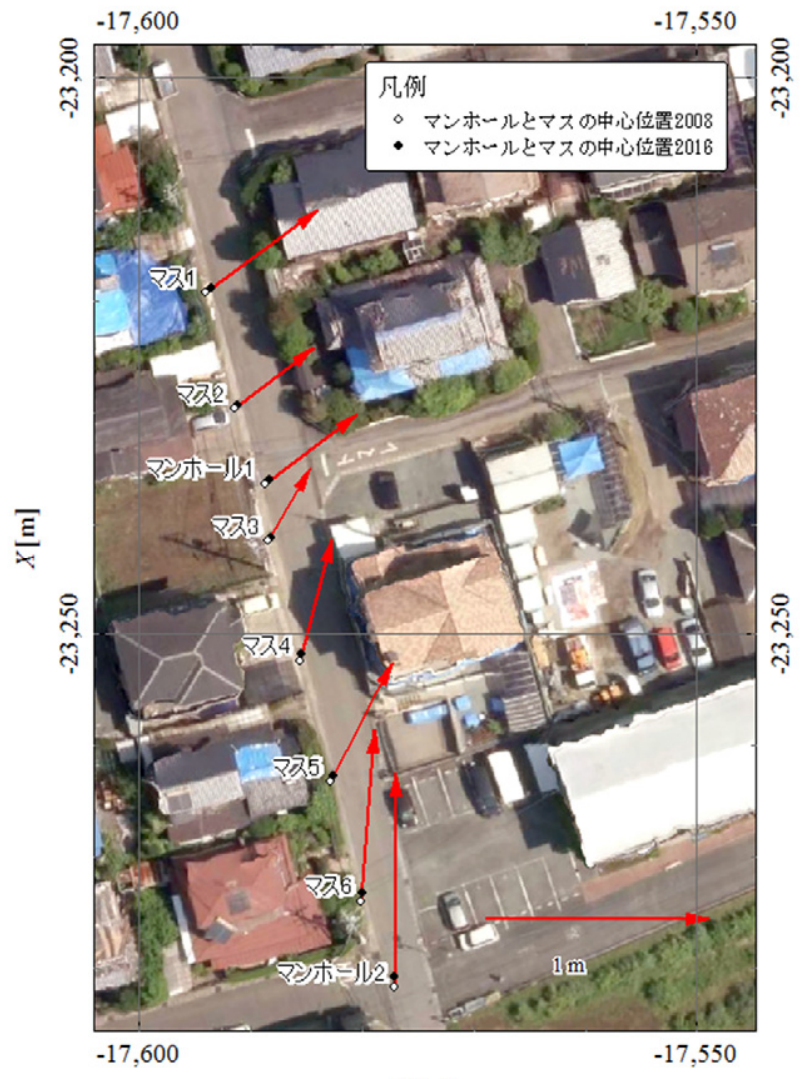

$Y[\mathrm{~m}]$

図-10 震災前後マンホールとマスの中心位置の較差ベクトル

全体的に $0.0 \sim 0.4 \mathrm{~m}$ ぼ隆起していると考えられる.

3) 阿蘇市的石・永草地域の検証点において, 震災後

DEMとGNSS測量の標高值を比較した. その結果,

震災前後DEMの差分は標準偏差 $0.118 \mathrm{~m}$ の精度で確 からしいことが確認された。

4) 益城町安永地域の検証点において, GNSS測量およ びオルソフォトモザイクの座標值を比較した．その 結果, 作成した震災後オルソフォトモザイクの水平 位置は標準偏差0.117 mの精度で確からしいことが確 
認された.

5) 作成した震災後オルソフォトモザイクの水平位置の 標準偏差 $0.117 \mathrm{~m}$ は，ネットワーク型RTK法VRS方式 GNSS測量による標準偏差 $0.01 \mathrm{~m}$ 程度より大きいもの の，台帳図による標準偏差 $0.3 \mathrm{~m}$ 程度より小さいこと から，この手法と精度は，ライフライン構造物の被 害との対比を目的として，災害によってGNSS測量 をライフライン構造物に対して行えない場合，有効 であると考えられる。

6) 益城町安永地域において，震災前後マンホールとマ スの中心位置座標を計測した，その結果，水平変状 を面的かつ定量的に明らかにすることができた。

7) 本研究の提案手法による成果は，三角点と異なって 面的に水平変状を明らかにでき，地壳変動による複 雑な地表面の変状を捉えられる可能性を示した.さ らに，地表面のライフライン構造物の変状を個別に 着目できるため, 地表面の変状とライフライン構造 物の被害との対比分析に役立てる可能性を示唆した. 標定方法, 幾何変換方法, 使用するソフトウエアによ って精度が異なること，写真測量技術の向上によって精 度が向上することが明らかであるので，現在の手法と精 度を示しつつ高精度を目指して研究を蓄積する必要があ る.

謝辞 : 本研究で用いた空中写真は, 熊本県等が実施する 復旧の支援のため, 国土地理院非常災害対策本部情報提 供支援班から提供いただいた。国土地理院非常災害対策 本部情報提供支援班に感謝申し上げる.

\section{参考文献}

1) 矢来博司, 小林友勝, 森下遊, 藤原智, 三浦優司, 宮原伐折羅，SAR 解析グループ：だいち 2 号の干渉 SAR による熊本地震の地殼変動の把握, 写真測量と リモートセンシング, Vol.55, No.3, pp.166-167, 2016.

2) 小林浩, 三浦博之：二時期の垂直写真から見る変状 と被害，写真測量とリモートセンシング，Vol.55， No.3, pp.158-159, 2016.

3) 石黒聡士, 松多信尚, 井上公, 中田高, 田中圭, 石 山達也，箕田友和，竹竝大士，森木ひかる，廣内大 助 : UAV を用いた平成 28 年熊本地震の地表地震断層 の撮影と地形モデル作成, 日本リモートセンシング 学会誌, Vol.36, No.3, pp.214-217, 2016.

4) 国土地理院基本図情報部災害対策班, 国土地理院ラ
ンドバード : 平成 28 年熊本地震の緊急撮影活動, 写 真測量とリモートセンシング, Vol.55, No.3, pp.152153, 2016.

5) 高橋陪夫, 石野達哉, 櫻井洋祐, 宮崎景太, 千葉丈 久, 高田裕司, 山本英子, 根本沙織, 内藤一郎, 田 殿武雄, 大木真人, 夏秋嶺, 永井裕人, 石原光則, 本岡毅，鈴木新一：だいち 2 号および国際チャータ・ センチネルアジアによる平成 28 年熊本地震の対応. 写真測量とリモートセンシング, Vol.55, No.3, pp.154-155, 2016.

6) 古田竜一, 小林優介：FORMOSAT-2 衛星による平成 28 年熊本地震の観測, 写真測量とリモートセンシン グ, Vol.55, No.3, pp.156-157, 2016.

7) 千葉達朗, 織田和夫, 高山陶子, 藤田浩司 : 航空レ ーザ計測差分による熊本地震本震前後の益城町近辺 の変状解析，写真測量とリモートセンシング，Vol.55, No.3, pp.160-161, 2016.

8) 頓田修一朗, 阿部直樹, 榊原庸貴, 望月貫一郎： PALSによる平成 28 年熊本地震の災害撮影について, 写真測量とリモートセンシング，Vol.55，No.3， pp.162-163, 2016.

9) 石塚師也, 辻健, 松岡俊文 : 2016 年熊本地震に伴う 江津湖・水前寺周辺の局所的な地表変動, 日本リモ ートセンシング学会誌, Vol.36, No.3, pp.218-222, 2016.

10) 濱田政則, 恵本克利, 磯山龍二, 安田進 : 地盤の永 久変位と地震被害について, 地震工学研究発表会講 演概要, Vol.18, pp.349-352, 1985.

11) 久保慶三郎, 濱田政則, 磯山龍二：日本海中部地震 における地盤の永久変位の測定, 地震工学研究発表 会講演概要, Vol.18, pp.353-356, 1985.

12) 濱田政則, 安田進, 磯山龍二, 恵本克利 : 液状化に よる地盤の永久変位の測定と考察, 土木学会論文集, No. 376/III-6, pp. 211-220, 1986.

13) 濱田政則, 磯山龍二, 佐藤修 : 液状化による鉛直方 向の地盤の永久変位, 地震工学研究発表会講演概要, Vol. 19, pp. 181-184, 1987.

14）国土地理院 熊本地震で変動した基準点の新しい成 果を公表： http://www.gsi.go.jp/sokuchikijun/sokuch ikijun60019.html (2016 年 10 月 31 日閲覧)

15）久保寺貴彦, 那須充, 草野克己, 姫野賢治 : 基準点 測量，細部測量および GIS による下水道施設を対象 とした高精度 3D データ作成, 土木学会論文集 F3 (土 木情報学), Vol. 71, No. 1, pp. 30-42, 2015.

16）国土交通省地籍調査 Web サイト都市再生街区基本調 査及び都市部官民境界基本調査の成果の提供システ ム: http://gaikuchosa.mlit.go.jp/gaiku/ (2016年 11 月 3 日 閲覽)

(2016. 11. 4 受付, 2017.1. 4 修正, 2017. 2. 18 受理) 


\section{ANALYSIS ON SURFACE DEFORMATION BY 2016 KUMAMOTO EARTHQUAKE USING GNSS AND PHOTOGRAMMETRY}

\section{Takahiko KUBODERA, Takanobu SUZUKI, Hiroshi MASAHARU and Eiji MATSUO}

The 3-D model of surface deformation was made by aerial photogrammetry and the GNSS surveying was also done in the actual ground, in order to clarify the surface deformation by the 2016 Kumamoto Earthquake. At the verification points, the accuracy of the constructed model was verified. The surface deformation was analyzed by overlaying the 3-D model after the earthquakes on the 3-D model before the earthquakes using GIS. The difference between the DEM before the earthquakes and the DEM after the earthquakes was analyzed in Matoishi and Nagakusa area, Aso-shi. As the result, the vertical surface deformation could be found two-dimensionally and quantitatively. The coordinate values at the center of gully holes and manholes before and after the earthquakes were also measured in Yasunaga area, Mashiki-machi. As the result, the horizontal surface deformation could be found two-dimensionally and quantitatively. 